International Journal of Social Science And Human Research

ISSN(print): 2644-0679, ISSN(online): 2644-0695

Volume 05 Issue 02 February 2022

DOI: $10.47191 / \mathrm{ijsshr} / \mathrm{v} 5-\mathrm{i} 2-25$, Impact factor-5.586

Page No: $583-592$

\title{
Determinants of Student Activism in State Universities in Sri Lanka
}

\author{
Dimuthu Kumari, M.S. ${ }^{1}$, Fernando, R.L.S. ${ }^{2}$ \\ ${ }^{1,2}$ Department of Public Administration, Faculty of Management Studies and Commerce, University of Sri Jayewardenepura, Sri \\ Lanka
}

\begin{abstract}
Producing high-quality human resources is one of the main aims of the state university system in Sri Lanka. However, the smooth functioning of the state university system is sometimes interrupted by student activism. Even though the purpose of activism is reasonable on students' hands, it creates a huge social and economic cost in practice. Various measures have been taken to reduce the negative impact of activism; however, those measures appear to be less effective as the trend has been continued over the period. Hence, the purpose of this study was to identify the determinants of student activism. A questionnaire survey method was used to collect data and a quantitative approach was used in the study under the deductive reasoning method. The results revealed that a higher level of social networking, lower level of social commitments, and left-wing political ideologies stimulate students towards activism. The high level of social networking is the most influential determinant among others. The findings revealed that the factors like administrative failures, the social status of parents, and university subculture were not significantly influenced on activism in the Sri Lankan context. The findings of the study will be useful for administrators in making future policy decisions regarding student activism.
\end{abstract}

KEYWORDS: Student Activism; Determinants; State Universities

\section{INTRODUCTION}

The world rapidly moves towards a knowledge-based economy. Hence, the education system, particularly the Higher Education (HE) system plays a prominent role in the creation of such an environment. The higher education system in Sri Lanka has no exception in this endless run. It is made up of 16 state universities and nearly 50 private higher education institutions (University Grant Commission (UGC) Sri Lanka, 2021). Among them, the contribution of State Universities (SU) towards the socio-economic development of the county is unrivaled. Yet, the smooth functioning of the state university system in Sri Lanka is interrupted by student activism, and it has been a prolonged issue in the country. The political influence over the student union activities was often recorded in Sri Lankan history. Thereby, historical incidents of student activism have been deeply embedded with youth unrest and political turmoil particularly, during the period of the 1980s (Hettige 1996, Weeramunada 2008 \& Peris 1995). As noted by UGC (2017) student politics is a significant phenomenon in university education in Sri Lanka. The image of state universities has been harshly wounded over the last few decades due to the negative impact of student activism (UGC 2012). Many authors have discussed the destructive nature of student activism in Sri Lanka particularly in a historical context. Though it is not measured numerically, this cost includes the incidents of deaths, injuries, custody, arrest, and suspension of students, damages to public properties, and closure of universities. As a result of continual student activism, many parties including students, university administrators, and the government endure pains. Student activism heavily distracts the studies in one aspect. Previous records are evident for the assassinations, injuries, arrests, and suspension of students in Sri Lanka. On the aspect of university administration, incidents of taking hostages including Vice-Chancellors, putting barriers for university facilities, and damaging properties, are reported in Sri Lankan state universities (University Grant Commission (2012). The Vice-Chancellors and administrators of the state universities are often hampered by handling this type of destructive act, whereby their valuable time and energy could otherwise be used on concentrating and engaging in other works in the institutions (University Student Charter 2012). Explaining the severity of student politics in Sri Lanka, Weeramunda (2008) reports the deaths of two senior academics (one a Vice-Chancellor and the other a retired Vice-Chancellor) in 1989 at the hands of assassins connected with the left movement in two separate universities. Concluding his work, he emphasized the negative results of student activism as disruption to the educational career prospects of students; interference with the career development of university staff; causing restraints of the employment opportunities available for university graduates, and impediment in the stability of the government.

However, the nature of student activism in Sri Lanka in the present context has been changed to a greater extent. Samaranayaka (2013) has identified the historical student movements in Sri Lanka as 'value-oriented movements' (students 


\section{Determinants of Student Activism in State Universities in Sri Lanka}

highly focused on broader ideological issues like Marxism, inequality, ethnonationalism, etc) whereas the contemporary student activism (see table 01), can be seen as 'norm-oriented movements' (highly focus on specific, inward-looking issues such as student's welfare, student's rights, university reforms, or a particular government policy).

Table 01: Student protest activities in Sri Lanka during the decade of 2008-2018

\begin{tabular}{|c|c|}
\hline Year & Protest Incident \\
\hline 2008 & $\begin{array}{l}\text { Inter-University Students' Federation (IUSF) protests since } 2005 \text { demanding an increase of 'Mahapola' } \\
\text { from Rs. 2,500 to Rs. 5,000. (A welfare subsidy given by the Government of Sri Lanka to State university } \\
\text { Students) }\end{array}$ \\
\hline 2009 & Continued the same movement. \\
\hline 2010 & $\begin{array}{l}\text { IUSF Protests for opposition to the privatization of universities and followed by worsening conditions on } \\
\text { campuses. }\end{array}$ \\
\hline 2011 & $\begin{array}{l}\text { IUSF protests to release their fellow students, arrested during protests against the privatization of state } \\
\text { universities. }\end{array}$ \\
\hline 2012 & Continued the same. \\
\hline 2013 & IUSF protests against 'collecting charges in government schools which provide 'free education. \\
\hline 2014 & $\begin{array}{l}\text { Paramedical student protests demanding few claims 1) demanding for the examination admission to the } \\
\text { fourth batch of the nursing course; 2) forcing to stop the suppression of students by imposing prevention } \\
\text { of entry to examinations; } 3 \text { ) forcing to stop obstructions caused for their extracurricular activities by the } \\
\text { administration. }\end{array}$ \\
\hline 2015 & $\begin{array}{l}\text { IUSF protests for assisting Higher National Diploma in Accountancy (HNDA) students in the Sri Lanka } \\
\text { Institute of Advanced Technological Education (SLIATE) to force the government to demand the degree } \\
\text { status for their Diploma which lasts for four years. }\end{array}$ \\
\hline 2016 & IUSF protests against establishing Private Medical Faculties in the University system \\
\hline 2017 & Continued the same \\
\hline
\end{tabular}

Source: (Dimuthu Kumari \& Fernando, 2021)

These events show that modern student activists are highly norm-oriented as per the categorizations of Samaranayaka (2013). However, many of those events were ended up bringing a positive impact to society, thus administrators need to carefully understand the discontent of students without waiting for them to start protests. When their voice is not heard, the pressure comes out by the means of strikes, protests, aggressive demonstrations, and other types of movements. Although facilities and other services in state universities are developed up to some extent, the intensity of student activism also simultaneously has strengthened over the past few decades. They start protest activities for fair enough reasons, but, in practice, the behavior of activists seems violent and annoying basically due to the traffic jams and property damages. Activism is not to be welcomed or feared, but, effective handling of them requires a proper identification of root causes. In this context, administrators appear to be less serious when distinguishing the constructive and destructive potentials of student movements in Sri Lanka. Rather than approaching students with armed forces, there are many mechanisms to mediate student movements smoothly. More specifically, administrators should find out why students are mobilizing in movements increasingly. Therefore, the problem statement of the current study is, what are the critical factors behind student activism in the Sri Lankan state university system. Accordingly, the research objective of the study is; To find out the critical factors that stimulate student activism in the state university system, Sri Lanka. The findings of the current study would be useful in making policy decisions regarding the state university system.

Much of the previous research on student activism is descriptive and seeks to explain some of its features like causes and effects (see Lee 1997; Hoge et al 2017, Wood 2017), global and local trends (see Weiss \& Meredith 2013; Barcan \& Alan 2007; Donald 2017), social perspectives on student activism (see Herr \& Edwin 2017), and the impact of student activism (see Sheppard 1989; Tsui 2000; Sax, 2004; Barnhardt Sheets \& Pasquesi 2015; Kezar 2010; Rhoads Saenz \& Carducci 2005) as cited by Cassie \& Kimberly (2016). Despite the plethora of research works, no proper theoretical base or robust definitions on student activism could be found. Both terms, 'Student Activism' and 'Student movement' are interchangeably used in previous works.

\section{Student Activism}

Student activism is a complex phenomenon. It is a movement organized and carried out by campus students that address issues of social justice, both political and economic, or structural or institutional change (Ramio \& Joslyn 2002). Student activism can be violent or peaceful, noisy or quiet, small or huge (Jordan 2002). It is a public display enacted by students to express their displeasures. Oxford dictionary (2017) defines activism as a policy or action of using vigorous campaigning to bring about 


\section{Determinants of Student Activism in State Universities in Sri Lanka}

political or social change. For this study, student activism is defined as a struggle of students stimulated by various social, political, and personal factors in defense of social or individual interests.

\section{Student movements}

Fletcher (2005) explains student movement as one main form of social movement. A social movement is an organized effort of many people to bring about or impede social, political, economic, or cultural change (McAdam \& Snow 1997). Though there is no widely accepted theoretical perspective on student activism, however, there are various theories on social movements which can be used to describe how students are recruited into activism (Rosas 2002).

\section{Theories on Student movements}

Social movements today are highly complex, and no single theory alone would be able to explain them. Therefore, this study uses the multifactor theory (value-added theory) suggested by Smelser (1962). It provides a more comprehensive analysis in determining factors that attract students towards the movements. Smelser in his multifactor theory mentioned that six factors are needed and adequate for the origin of social movements namely 1) structural conduciveness, 2) discontent, 3) shared beliefs, 4) dramatic events, 5) social networking to mobilize people, and 6) the level of control put by those in power.

The first factor is structural conduciveness. It is the essential characteristic of a society that makes the rise of social movements possible. The existing structure of the society lets people get together for social movements. The social structure itself enables people to join movements with some favorable conditions like democracy, free media, freedom of assembly, and speech. The second factor discussed in the theory is the strain (discontent) created by the social system. It tells that the deprivation of people in terms of expectations, aspirations, or moral ideals will lead them into movements. Many classical theorists agree that the direct cause of any social movement is an individual's disrupted psychological state and the result of some form of grievance (Harberman 2006). Further, supportive literature is found in (Agnew 1992; Featherstone \& Deflem 2003; Smelser 1963; Morrison 1971). As such, this second factor is highly related to the relative deprivation theory. Relative deprivation theory discusses the depreciation of people in two aspects; called egoistic deprivation and fraternal deprivation (Singer 1992). Egoistic deprivation refers to a single individual's feeling of comparative deprivation which will not be a reason for social movements whereas fraternal deprivation refers to the discontent of the entire group as compared to a referent group. Hence, student activism can be identified in terms of fraternal deprivation. Gurr (1971) has discussed psychological frustration as the root cause of social movements in his famous book 'Why men rebel'. Some authors (Esman \& Eriksen 1993) discussed student protests as a result of relative deprivation; cited by Saleh (2013). The third factor discussed in multi-factor theory is sharing of $a$ generalized ideology. It discusses the influence of the shared ideology of the activists to join the movements. They have some common feelings on the discontent, and they all believe that the discontent could be resolved through activism. The literature says that the clearly defined, commonly agreed and understandable ideologies will be successful in social movements. The fourthly discussed point is precipitating factors. These are dramatic events that confirm or justify the generalized belief and attract people to join with activism. The fifth factor is strong social networks of leaders to mobilize people. Participants have a strong social network that helps achieve the final goals of the movements. The final factor discussed is the level of social control. This factor discusses the level of control put by the rulers over the social movements. They either will or will not react to the social movements. High levels of controlling mechanisms often make it more difficult for social movements to come up with their goals.

\section{Determinants of student activism}

The determinants of student activism are extensive. Some of the main factors focused on by previous authors are mentioned in the following section as they facilitated the creation of the model of this study.

1) Administrative Deficiencies in Universities - A variety of deficiencies in the administrative aspect of the university system, leads to student activism (Burgess \& Hofstetter 1971; Janc 2004; Weeramunda 2008). Corrupted practices of state university administration particularly using the tender system for obtaining hostel facilities, running canteens, hiring security staff from the private sector, or color washing buildings stimulate students' consciousness about university administration, and they tend to sand up (Weeramunda 2008). Some other administrative failures, such as lack and not assigning enough responsibility to students to take a share in management; lack of uniform policy or rules for handling activism (Ellsworth F. and Burns M. 1970); rigid compartmentalization into faculties and departments that produces a sense of isolation of academics and staff from the student body; interference from outside politicians in university affairs (Weeramunda 2008) are also mentioned in the literature.

2) Social status of the parents (influence of family) - Family influence is discussed by many authors but in contradictory nature. As mentioned by Lee (1997) activist the student is likely to accept the basic political and social values of his parents. Also, Flacks (1970) states that politically active students often tend to reflect their parents' values. Another proponent idea was given by Weeramunda (2008) saying that the students are more aligned with the working class; usually come from the rural working class who have a leftist political ideology. However, some western literature reports that student activists coming from higher socioeconomic backgrounds than non-activists do (Astin,1970; Franz \& McClelland 1994; Kahn \& Bowers,1970; Lipset,1971; Sherkat 


\section{Determinants of Student Activism in State Universities in Sri Lanka}

\& Blocker 1994), and from such families that emphasize academic achievement as a way to foster a strong intellectual identity (Baird 1970; Heffernan 1992; Sherkat \& Blocker 1994), as cited by Rosas (2010).

3) Availability of a Larger Social Network (Structural Availability) - Structural availability refers to the presence of interpersonal networks that facilitate mobilization or recruitment to activism (Schussman \& Soule (2005), cited by Rosas (2002). Indeed, individuals are more probable to be involved in activism when having strong 'social networks'. Several empirical studies have supported that networks are important in student activism (Klandermans \& Oegema 1987; McAdam 1986; McAdam \& Paulsen1993; Morris 1981; Passy \& Giugni 2001; Paulsen 1991; Snow Zurcher Eckland-Olson 1980; Walsh \& Warland 1983) as cited by Rosas. Jones \& Hill (2003) stated that friends and peers played a significant role in influencing participation in activism. Dyke (1998) found that institutions, where students can maintain a greater number of connections with other students, are more prone to protest activities. Much the same as the above authors, Lee (1997) has also found that college socialization which emerges through various social networks, has an important role in student activism.

4) Lack of Social Commitments (Biographical Availability) - Past studies have found that 'lack of social commitments' as a matter of fact in student activism. When the students are free of societal constraints than other groups in the population, they are better able to act decisively on political issues. Students are usually not working for a living and many of them have no family responsibilities. Hence, they often live away from home in a peer group subculture. This factor has been discussed by McAdam (1986, p.70) using the terminology Biographical availability which simply refers to the absence of personal constraints that may increase the costs and risks of movement participation, such as full-time employment, marriage, and family responsibilities.

5) Influence of Left-wing Political Ideologies - Lee (1997) confirms the evidence that left-wing political beliefs play a significant role in participating in protest activities. According to him, students who are radically socialized via left-wing political ideas are more likely to exhibit their preference for communism and high levels of support for protest activities. Thus, Revolutionary ideologies undoubtedly added conviction and an increasingly militant tone to the nationalist movement particularly in the Asian context whereby student participation is motivated (Altbach 1984). According to him the activists, played a key role in disseminating ideas like nationalism, radicalism, or modern ideologies to society as they are the first groups to feel the pull or attraction of modern ideas.

6) Influence of university subculture - Universities have unique cultures, histories, and practices that contribute to student political consciousness and concern (Berghe 1973; Altbach 1972) as cited by Altbach (1984). The environment, curriculum, and policies of the university have an important effect on student activism (Altbach 1972). He also explained the nature of university culture and its impact on activism. Survey research indicates that more liberal individuals are more likely to engage in student activism (Lipset 1976); cited by Dyke (1998). Also, the subculture of the university and intellectuals generally examines carefully and critically the society whereby the subculture is a part (Shils 1972). As suggested by many authors (Dyke 1998; Altbach 1984; Shils1972; Kahn \& Bowers, 1970) it is necessary to understand the nature of the university and its culture and convenience for students, to understand fully and embrace student politics. When the elements of the subculture are threatened, it creates unrest among students which essentially might have an impact on activism. Dyke (1998) notes historical evidence suggesting that the students of the 1960s were influenced by these subcultures a lot.

7) Physical Environment \& Welfare Facilities in Universities - Institutional milieu and welfare facilities of universities play a significant role in student politics (Janc 2014). Citing the works of Shils (1972), Altbach (1984) mentioned that the educational and institutional environment of activism is of crucial importance. Some authors (Lipset 1971; Sherkat \&

Blocker 1994; Soule 1997) have reported that the physical geographical location of universities and the level of given welfare facilities have an impact on student activism; cited by Rosas (2010).

\section{Development of Hypotheses}

Based on the literature, seven predictors were developed to examine their relationship with student activism. Accordingly, the main hypothesis of the study was;

$H_{1}$ : There is a statistically significant relationship among Administrative Failures in Universities; Social Status of parents; Level of Social Networking; lower level of Social Commitments; Influence of Left-Wing Political Ideologies; Poor welfare Facilities; Influence of University Subculture and Student Activism.

A Conceptual framework including seven predictors was developed based on the extant literature review explaining stimulating factors of student activism. 


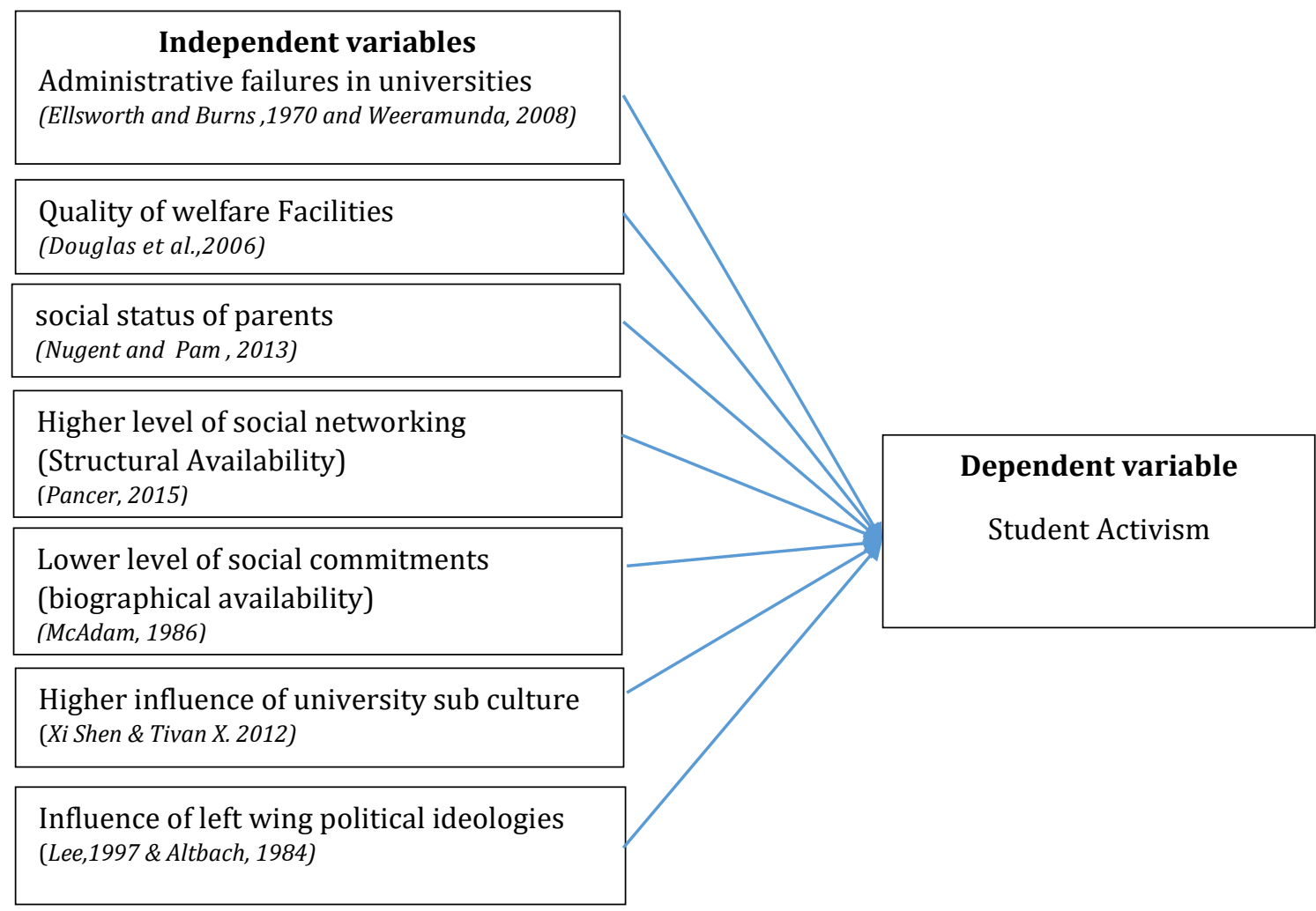

Figure 01 - Conceptual framework which describe the determinants of student activism Source: Based on Literature

\section{Working definitions of variables}

The questionnaire was developed using 85 items under the constructs and they were derived from the operationalization of working definitions found in the literature. These working definitions are shown in the following table.

Table 2: Working definitions of variables

\begin{tabular}{|c|c|c|}
\hline Variable & Operational/working definition & Source/s \\
\hline $\begin{array}{l}\text { Student Activism } \\
\text { (SA) }\end{array}$ & $\begin{array}{l}\text { Student Activism should be measured in terms of behavioral } \\
\text { commitment of students which is the amount of physical or } \\
\text { psychological effort devoted by the students to address the } \\
\text { political, economic, social, or institutional issues in a given } \\
\text { context. }\end{array}$ & $\begin{array}{l}\text { Lee (1997); Astin (1999) } \\
\& \text { Ramio and Joslyn } \\
\text { (2002) }\end{array}$ \\
\hline $\begin{array}{l}\text { Administrative } \\
\text { Failures in } \\
\text { Universities (AFU) }\end{array}$ & $\begin{array}{l}\text { Failures in university administrative policies are } \\
\text { characterized by not giving an adequate amount of } \\
\text { responsibility to students to take a part in management; lack } \\
\text { of uniform policy for handling activism; isolation of staff } \\
\text { from the student body and corruption in administration } \\
\text { particularly procurement and recruitment. }\end{array}$ & $\begin{array}{l}\text { Ellsworth F. and Burns } \\
\text { M. (1970) and } \\
\text { Weeramunda (2008) }\end{array}$ \\
\hline $\begin{array}{l}\text { Quality of } \\
\text { University } \\
\text { facilities (QUF) }\end{array}$ & $\begin{array}{l}\text { University facilities are the services provided by the } \\
\text { university to contribute to students' academic and personal } \\
\text { life by enhancing their satisfaction. }\end{array}$ & Douglas et al., (2006). \\
\hline $\begin{array}{l}\text { Social Status of } \\
\text { Parents } \\
\text { (SSP) }\end{array}$ & $\begin{array}{l}\text { Social status is the relative prestige, authority, or privilege of } \\
\text { a person which can be primarily measured by either income } \\
\text { level or educational level. }\end{array}$ & $\begin{array}{l}\text { Nugent and Pam M.S., } \\
\text { (2013) }\end{array}$ \\
\hline $\begin{array}{l}\text { Level of Social } \\
\text { Networking (LSN) } \\
\text { (Structural } \\
\text { availability) }\end{array}$ & $\begin{array}{l}\text { 'Structural availability' denotes the presence of interpersonal } \\
\text { networks that facilitate recruitment to activism and these } \\
\text { social networks can be either inside or outside }\end{array}$ & $\begin{array}{l}\text { Schussman \& Soule, } \\
\text { (2005), p. } 1086 \text { and } \\
\text { Zaff, Malanchuk and } \\
\text { Eccles (2008) cited by } \\
\text { Pancer S.M. (2015) }\end{array}$ \\
\hline
\end{tabular}




\begin{tabular}{|c|c|c|}
\hline $\begin{array}{l}\text { Lack of Social } \\
\text { Commitments } \\
\text { (LSC) } \\
\text { (Biographical } \\
\text { Availability) }\end{array}$ & $\begin{array}{l}\text { 'Biographical Availability' denotes the absence of personal } \\
\text { constraints such as employment, marriage, and family } \\
\text { responsibilities. }\end{array}$ & McAdam, (1986), p. 70. \\
\hline $\begin{array}{l}\text { Influence of } \\
\text { University } \\
\text { SubCulture(IUSC) }\end{array}$ & $\begin{array}{l}\text { Campus Subculture is the blend of various cultures on } \\
\text { campus which mainly comprises three aspects - material } \\
\text { culture, institutional culture, and spiritual culture. }\end{array}$ & $\begin{array}{l}X i \text { Shen \& Tivan } X \text {. } \\
(2012)\end{array}$ \\
\hline 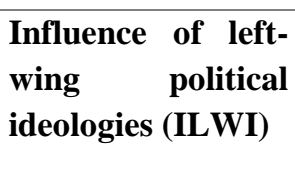 & $\begin{array}{l}\text { Leftist students are those who are highly aware of left-wing } \\
\text { ideologies and exhibit their support for left-wing parties and } \\
\text { their protest activities and are highly aware of current social } \\
\text { issues in the society. }\end{array}$ & $\begin{array}{l}\text { Lee, (1997) \& Altbach, } \\
\text { (1984). }\end{array}$ \\
\hline
\end{tabular}

Source: Based on the literature

\section{RESEARCH METHODS}

This study was conducted to identify the determinants of student activism. This has a strong commitment to the positivist research paradigm with an emphasis on measurement, predictions, and quantitative data analysis. Hence, this was carried out under the deductive reasoning approach. Within the field of student activism research, there are a few studies that have followed a similar methodology (Prizzia \& Rosario, 1971; Dyke 1998; Bamhardt, 2012; Zilvinskis et al 2020). By operationalizing the selected working definitions for each variable, a structured questionnaire was developed and distributed using a survey method. This study identified 'student leaders' as the representatives of students who have

been officially appointed as per the constitutions of student unions. According to the constitution of student unions in SL, there are five key positions called President, Vice President, Secretary, Treasurer, and Editor. Moreover, there are two faculty representatives for each faculty, and the number of faculty representatives who represent the main university is different from one university to another based on the number of faculties. Hence, the population of the study comprises student union leaders in ten selected state universities (University of Colombo, Peradeniya, Kelaniya, Sri Jayewardenepura, Moratuwa, Ruhuna, Sbaragamuwa, Rajarata, Jaffna, and Wayamba) in Sri Lanka, which amounts to 160 in the current context. Some state universities were purposely removed from the study with the facts that not have a strong student union or have different subcultures.

Hence the total population amounts to 160 and questionnaires were distributed to the whole population. 124 completed responses were received, and the response rate was $77 \%$. Therefore, the sample was taken as 124 and this figure was deemed to be a good representative of the population as per Morgun (1970). The stratified random sampling technique was used. Each selected university was considered as a stratum in the population and the researcher approached more than 50 percent of each stratum. Respondents were informed about the purpose of the study and their consent was taken. Data were analyzed using descriptive and inferential statistics and the Statistical Package for Social Sciences (SPSS) version 24 was used.

\section{RESULTS AND DISCUSSION}

\section{Discussion on the demographic profile of the sample}

Some common characteristics of the respondents were identified in the demographic analysis. The majority (60\%) of student leaders of the main student body are coming from social science backgrounds. Though there are student leaders in facultywise student associations, the main student union of many universities represents by the social science students. When considering gender, the majority $(84 \%)$ are male student leaders. Though the university student population is island-wide scattered, it was identified that the majority of (73\%) of the student leaders come from rural areas and the majority (78\%) of their parents are working in the informal sector. And 58\% of the student leaders are staying at university hostels in contrast to the other accommodation like boarding places, relative's places, etc. Having girlfriend/boyfriends is a common incident among many university students, however, it was noteworthy that the many student leaders who responded to the current study, are single and they have no girlfriends/boyfriends. The majority $(64 \%)$ of respondents are not doing part-time jobs and cover their expenses with government bursaries. Many of them are not following professional courses. Many activists mentioned that their parents have not gained higher education, and some are not even the primary education. Finally, this group, being the leaders in unions or associations is actively engaged with planning, organizing implementing the movements. Therefore, they were identified as the most active group in the case of student activism. Many of these identified characteristics discussed here comply with the individual characteristics discussed in the Relative Deprivation Theory. 


\section{Determinants of Student Activism in State Universities in Sri Lanka}

\section{Discussion on data analysis \& Results}

Data analysis was conducted using the SPSS software and mainly, descriptive and inferential analysis techniques were used. The normality of the data set was assured by observing skewness and kurtosis values. It was decided that the normality requirement of the data set is fulfilled since all skewness and kurtosis values were in between +2 and -2 . Reliability of the data was assured by Cronbach's Alpha values, they all were above 0.7 thus, a good internal consistency was observed. KMOBartlett's tests were performed to check the validity of the collected data. When confirming the validity recommendations of Kaiser (1974), (Azaid, 2011), Fonrnell and Larcher, (1971), were used. Factor analysis was conducted to further ensure the convergent and discriminant validity and used the recommendations given by Hair et al. (2010). Out of a total of 85 items, 12 items were removed due to the lower factor loading. Each factor loading was significant at a 95 percent level of significance. To determine whether there is a correlation between variables, the Pearson Correlation coefficient was examined. It was observed that there was a significant relationship between student activism and all the independent variables. It was hypothesized that the administrative failures in universities, social status of parents, higher level of social networking, lower level of social commitments, the higher influence of left-wing political ideologies, and influence of university subculture of activists might have an impact on student activism.

Regression analysis was used to observe changes in the dependent variable with the changes in independent variables. As shown in table no.4, only three variables were taken into the model and the other four were excluded.

Table 03: Results of the Hypotheses testing

\begin{tabular}{llll}
\hline & Independent Variables & P-value/sig & Result \\
\hline H1 & Administrative Failures in Universities & .445 & Rejected \\
\hline H2 & Social Status of parents & .224 & Rejected \\
\hline H3 & Higher level of Social Networking & .001 & Accepted \\
\hline H4 & The lower level of Social Commitments & .000 & Accepted \\
\hline H5 & Influence of Left-Wing Political Ideologies & .008 & Accepted \\
\hline H6 & Quality of University Facilities & .782 & Rejected \\
\hline H7 & Influence of University Subculture & .195 & Rejected \\
\hline
\end{tabular}

Source: Field data, 2018

This study found that there is a statistically significant relationship between a higher level of social networking (LSN), the higher influence of left-wing political ideologies (ILWI), and lower level of social commitments (LFC) and student activism since the P values of those variables are less than the threshold (0.05) value.

First, when the level of networking is high, they tend to engage more with activism. As per the respondents they usually link with the students in their university, student leaders in other universities, senior students, past office bearers of the union, journalists, some media personalities, etc. This finding is compatible with the literature since similar kinds of findings are recorded by previous studies too (Rosas 2010; Jones \& Hill 2003; Dyke 1998; Lee 1997). These authors have discussed a positive relationship between social networking and student activism. Further, this finding complies with the 'fraternal deprivation' discussed under the relative deprivation theory, as well as it can be supported with the 'strain factor' discussed under the multifactor theory of social movements. The fraternal deprivation discusses the origin of activism in terms of discontent of a large connected social group, compared to a referent group. Students have become intensely frustrated with privatization policies of education, limited welfare facilities in universities, and many other facts. Further, this collective feeling of deprivation strengthens their shared identity and it ultimately leads to social movements (Singer, 1992).

Next, this study found that there is a statistically significant relationship between the lower level of social commitments (Biographical Availability) and Student Activism. In this study, the term social commitments cover the student's obligations towards his parents, siblings, relatives, friends, villages, workplaces, or towards the society at large. When students don't have many social obligations (lower level of commitments), they tend to engage more in activism. Therefore, this study identified the level of social commitments, as a crucial factor behind student activism. A similar kind of finding was given by Altbach (1970) and McAdam (1986). However, the multifactor theory is silent about this factor.

Thirdly, this study found that there is a statistically significant relationship between the Influence of left-wing political ideologies and Student Activism. The previous literature also has confirmed the influence of leftwing political ideologies as a critical factor of student activism (Altbach 1984; Lee 1997; Lipset 1972, (p. 253); Janc 2004). The multifactor theory also has discussed the influence of generalized ideologies of society as a critical factor behind social movements. This study found that most student leaders believe in left-wing political ideologies. Also, they have common feelings on the discontent of the prevailing 


\section{Determinants of Student Activism in State Universities in Sri Lanka}

system, and they believe it could be resolved through activism. The literature supports the point that the commonly agreed and understandable ideologies will be successful in social movements. Hence, the findings comply with the arguments of multifactor theory.

Also, the variables are shown in Table 3 (Administrative Failures in Universities, Social Status of parents, Quality of University Facilities, Influence of University Subculture) which has higher $\mathrm{p}$ values than the threshold value (0.05), are statistically insignificant at 95 percent confidence level. Therefore, it was concluded that there is no significant impact of those independent variables on the dependent variable in the present context. Yet, the theory considered here covers the majority of the above-disqualified variables. Many of them are discussed by previous authors as significant factors in explaining student activism. Therefore, these factors must be further studied using other research methods, to find out why these are not influential in the Sri Lankan context. However, it is noteworthy here that the receiving of genuine and accurate responses is the main limitation of the current study.

Table 04: Influential ability of constructs

\begin{tabular}{llllll}
\hline model & Construct & $\begin{array}{l}\text { Adjusted } \\
\text { Square }\end{array}$ & $\begin{array}{l}\text { Influential Ability of } \\
\text { the construct as \% }\end{array}$ & $\begin{array}{l}\text { Changes } \\
\text { influencing } \\
\text { as \% }\end{array}$ & $\begin{array}{r}\text { of } \\
\text { ability }\end{array}$ \\
\hline $\mathbf{0 1}$ & Level of Social Networking & .298 & $29.8 \%$ & $29.8 \%$ \\
\hline $\mathbf{0 2}$ & Lack of Social Commitments & .366 & $36.6 \%$ & $6.8 \%$ \\
\hline $\mathbf{0 3}$ & $\begin{array}{l}\text { Influence of Left-Wing } \\
\text { Political Ideologies }\end{array}$ & .407 & $40.7 \%$ & $4.1 \%$ \\
\hline
\end{tabular}

Source: Field data, 2018

According to the changes of Adjusted $R$ Square value denotes above, 'the Level of Social Networking is the most powerful variable in the current study since it explains almost $30 \%$ of the dependent variable. The other variables are ranked accordingly, and the overall influential ability of the revised model is about $40.7 \%$ which can be considered as a significant amount in social science research.

\section{CONCLUSION}

Activism is natural in any context. This has been an essential requirement for many reforms in Sri Lanka, particularly in the higher education sector. The activists, initially suggest or oppose changes, and when their concerns are not heard, they start protests and ultimately ended up with large social movements. Though they have initially engaged in movements with good purposes, in the implementation stage the behavior of student activists seems more destructive. Hence, this study identified that proper understanding of the root causes behind student activism is important. However, this study may possess the inherited limitations of quantitative techniques, the structured written questionnaires, and sampling errors. Also, the reliability of data is a limitation, since the activists normally try to hide their identities in universities. Avenues for future research are shown about other variables that have affected Student Activism. Especially, demographic factors like ethnicity, religion, relationship status may have a moderating effect on student activism. Thus, further research can be conducted to identify such relationships. The scope of quantitative analysis is limited in the present study, but a more comprehensive qualitative analysis is open for further researchers, combing the perspectives of many stakeholders together.

\section{REFERENCES}

1) Agnew, R. (2001). Building on the foundation of general strain theory: Specifying the types of strain most likely to lead to crime and delinquency, Journal of research in crime and delinquency, vol. 38, 319-361.

2) Barnhardt and Cassie, L. (2012). Contemporary student activism: The educational contexts of socially-responsible civic engagement, University of Michigan. ProQuest Dissertations Publishing.

3) Blau, P., and Slaughter (1971). E. Institutional conditions and student demonstrations. Social Problems, pp.474-487.

4) Burgess, P.M. and Hofstetter, C.R. (1971). The "Student Movement": Ideology and Reality. Midwest Journal of Political Science, 15(4), p.687.

5) Charles, B.N. (1968). The Administrative Challenge of the New Student Activism: It Is Student Participation in the Planning of Curriculum, The Journal of Higher Education, Vol . 39, pp. 69-76.

6) Chandola, H. (2017). Growing Student Movement, Economic, and Political Weekly, Available at http://www.jstor.org/stable/4364620. , 11(20), pp.727-728. Accessed on 08-03-2017. 


\section{Determinants of Student Activism in State Universities in Sri Lanka}

7) Clarence, E., Tygart, and Norman H. (2017). A Research Note on Student Leftist Political Activism and Family Socioeconomic Status : The Pacific Sociological Review, Vol. 14, pp. 121-128, University of California Press.

8) Dimuthu Kumari M.S. \& Fernando, R.L.S. (2021). Dealing smoothly with student activism: reflections of activists and administrators in Sri Lankan state university system. Muallim Journal of Social Sciences and Humanities, 5(3), 85-99. https://doi.org/10.33306/mjssh/141.

9) Di Ramio and Joslyn (2002). When Spiders Unite, They Can Tie Down a Lion: Student Affairs Practice. The Vermont Connection, 23.

10) Donald K.E. (2017). Students and Politics in Developing Nations, Pacific Affairs, Vol. 42, pp. 567-568, Pacific Affairs press.

11) Douglas Kirby, (2017). A Counter-Culture Explanation of Student Activism, Oxford University Press, Available at http://www.jstor.org/stable/799485

12) Dyke N. (2017). Hotbeds of Activism: Locations of Student Protest, Oxford University Press.

13) Eckhardt, K.W. (1970). Religiosity and Civil Rights Militancy. Review of Religious Research, 11(3), p.197.

14) Ellsworth, F. and Burns, M. (1790). Student Activism in American Higher Education. Student Personnel Series 10. American College Personnel Association.

15) Feierabend, I.K. (1971). Why Men Rebel. By Ted Robert Gurr. (Princeton: Princeton University Press, 1970. Pp. 407. \$12.50.). American Political Science Review, 65(1), pp.194-196.

16) Fletcher, A. (2005). Guide to Social Change Led By and With Young People. Olympia, WA: Common Action

17) Garwe, E.C. (2007). Student Voice: Embracing Student Activism as a Quality Improvement Tool in Higher Education. Global Voices in Higher Education. IntechOpen.

18) Gorton, B.R.A., (2017). Militant Student Activism in the High Schools: Analysis and Recommendations. , 51(10), pp.545-549.

19) Herr, E.L. (2017). Student Activism: Perspectives and Responses Student Activism: Perspectives and Responses. 55(5), pp.219-233.

20) Hoge et al. (2017). Religion and Alienation as Factors in Student Activism. 33(4), pp.217-229.

21) Hoge, D.R. and Luidens, D.A. (1972). Religion and Alienation as Factors in Student Activism. Sociological Analysis, 33(4), p.217. https://doi.org/10.1111/j.2044-8309.1984.tb00645.x

22) Janc, J. (2004). The meaning of the student advisory board Faculty of the Graduate School, University of Maryland leadership development experience to the student board members.

23) Jayasundara, S. (2014). Higher Education Policy in Sri Lanka: Implementation in State Universities. Scientific Research Journal, II(II), pp.41-44.

24) Jenkins, C. J. (1983). Resource mobilization theory and the study of social movements. Annual Review of Sociology, 9 , 527-53

25) Kahn, R.M. and Bowers, W.J. (2017). The Social Context of the Rank-and-File Student Activist: A Test of Four Hypotheses. American Sociological Association.

26) L. Weiss, M. (2013). Student Activism in Malaysia: Crucible, Mirror, Sideshow. Journal of Social Issues in Southeast Asia, [online] 28(2), p.361. Available at:

http://carpetingnexus.com/student_activism_in_malaysia_crucible_mirror_sideshow.pdf [Accessed 21 May 2020].

27) Lazarsfeld, P. (2017). A Counter-Culture Explanation of Student Activism. Social Problems, 19, pp.203-216. Oxford University Press.

28) Lee, A.-R. . (1997). Exploration of the sources of student activism: the case of South Korea. International Journal of Public Opinion Research, 9(1), pp.48-65.

29) Lipset S.M., (2017). University Students and Politics in Underdeveloped Alsatian Countries, Comparative Education Review, Vo. 10, Special Issue on Student Politics, The University of Chicago Press.

30) Lipset, S.M. (1966). University Students and Politics in Underdeveloped Countries. Comparative Education Review, 10(2), pp.132-162.

31) McAdam, D., and Snow, D. A. (1997). Social movements: Conceptual and theoretical issues. Social movements: Readings on Their Emergence, Mobilization, and dynamics. Los Angeles: Roxbury Publishing Company

32) Manly, B.F.J. (2005). Multivariate Statistical Methods: A primer. 3rd ed. Chapman and Hall.

33) McAdam, D. and S Snow, D. (1997). Social movements: readings on their emergence, mobilization, and dynamics. Los Angeles: Roxbury Publishing Company.

34) Miles and Herbaman, (1994). Qualitative Data Analysis: An expanded sourcebook, Beverely Hills, Sage

35) Millward, P.and Takhar, S. (2019). Social Movements, Collective Action, and Activism. Sociology, 53(3), pp.NP1NP12. 


\section{Determinants of Student Activism in State Universities in Sri Lanka}

36) Morris, A. (2000). Reflections on Social Movement Theory: Criticisms and Proposals. Contemporary Sociology, 29(3), p. 445 .

37) Neff, C.B. (1968). The Administrative Challenge of the New Student Activism: It Is Student Participation in the Planning of Curriculum. The Journal of Higher Education, 39(2), p.69.

38) Oxford English Dictionary. (2005). 7th ed. Oxford: Clarendon Press.

39) Philip, B. and Hofstetter (2017). The Student Movement: Ideology and Reality, Political Science Association.

40) Rosas, M. (2010). College student activism: An exploration of learning outcomes. Pro Quest Dissertations and Theses. p.211.

41) Samaranayake, G. (2003). Changing University Student Politics in Sri Lanka: From Norm Oriented to Value Orient Student Movement. Third International Symposium, University of Peradeniya, 1(1), pp.22-29.

42) Swaminathan A. \& James B. Wade, (2000). Social Movement Theory and the Evolution of New Organizational Forms, The Entrepreneurship Dynamic in Industry Evolution, Stanford University Press.

43) Sheppard, P. (1989). The Relationship Between Student Activism and Change in the University, With Particular Reference to McGill University in the 1960s Faculty of Education, McGill University.

44) Snow, D. A., and Soule, S. A., (2009). A primer on social movements. New York, NY: W. W. Norton

45) Tian X. and Shen X., (2012). Academic Culture and Campus Culture of Universities, Higher Education Studies, Vol. 2, No. 2; June 2012.

46) Thomson, S.D. (n.d.). A Perspective on Student Activism, Theory into Practice, What Do All Those People Want? 8, pp.279-283.

47) University Grant Commission, Sri Lanka (2002). University Student Charter.

48) Van Dyke, N. (1998). Hotbeds of Activism: Locations of Student Protest. Social Problems, 45(2), pp.205-220.

49) Walker, I. and Pettigrew, T.F. (1984). Relative deprivation theory: An overview and conceptual critique. British Journal of Social Psychology, [online] 23(4), pp.301-310. Available at: http://doi.wiley.com/10.1111/j.20448309.1984.tb00645.x.

50) Weeramunda, A. (2008). Socio-political impact of student violence and indiscipline in universities and tertiary education institutes.

51) Zilvinskis, John, et al. (2020). "Measuring Institutional Effects on Student Activism." Journal of College Student Development, vol. 61, no. 3, 2020, pp. 372-378, 10.1353/csd.2020.0034.

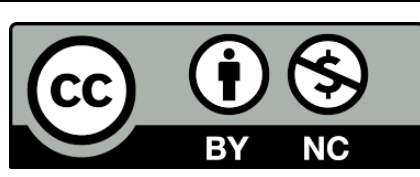

There is an Open Access article, distributed under the term of the Creative Commons Attribution - Non Commercial 4.0 International (CC BY-NC 4.0)

(https://creativecommons.org/licenses/by-nc/4.0/), which permits remixing, adapting and building upon the work for non-commercial use, provided the original work is properly cited. 